\title{
The Surgical Impact of E-Cigarettes: A Case Report and Review of the Current Literature
}

\author{
Megan Fracol ${ }^{1}$, Robert Dorfman ${ }^{1}$, Lindsay Janes ${ }^{1}$, Swati Kulkarni ${ }^{2}$, Kevin Bethke ${ }^{2}$, \\ Nora Hansen ${ }^{2}$, John Kim ${ }^{1}$ \\ ${ }^{1}$ Division of Plastic Surgery, Northwestern Memorial Hospital, Chicago; ${ }^{2}$ Lynn Sage Comprehensive Breast Center, Northwestern Memorial \\ Hospital, Chicago, IL, USA
}

\begin{abstract}
We report a case of a 51 years old female with a 25 pack year smoking history who underwent bilateral mastectomy and immediate tissue expander reconstruction for newly diagnosed right breast cancer. The patient reported herself as a non-smoker despite significant e-cigarette use, with resulting significant mastectomy skin flap necrosis and breast reconstruction failure. Little is known about the physiologic effect of e-cigarettes on wound healing and tissue perfusion. To this end, we provide an updated review of the impact of e-cigarettes on surgical outcomes. PubMed, Ovid MEDLINE, and PRS GO were searched for the terms "e-cigarette", "electronic cigarette", "e-cig", "electronic nicotine delivery system", "vaping", "surgery", "surgical", "peri-operative", "operate", "operative", and "wound healing". Abstract review of all articles was performed. 123 articles returned that contained both variants of e-cigarettes and surgery as keywords. Of those, manual assessment returned three articles which were found to be relevant to e-cigarette use in the surgical patient. No articles were found that compared perioperative complications in e-cigarette versus traditional cigarette users in humans. In conclusion, our case report depicts the potential dangers associated with e-cigarette use in the surgical patient. There is a public misconception that e-cigarettes are healthier than traditional cigarettes and as such their use may go unreported by patients. Early evidence suggests e-cigarettes may induce some of the same physiologic changes as traditional cigarettes, and may have a significant deleterious effect on wound healing.
\end{abstract}

Keywords Electronic cigarettes / Vaping / Nicotine / Wound healing / Surgery, plastic

\author{
Correspondence: John Kim \\ Division of Plastic Surgery, \\ Northwestern Memorial Hospital, 675 \\ N St Clair St \#19-250, Chicago, IL \\ 60611, USA \\ Tel: +1-312-695-6022 \\ Fax: +1-312-695-5672 \\ E-mail: john.kim@nm.org
}

Received: 18 Jan 2017 • Revised: 25 Jul 2017 • Accepted: 8 Aug 2017

pISSN: 2234-6163 • elSSN: 2234-6171 • https://doi.org/10.5999/aps.2017.00087 • Arch Plast Surg 2017;44:477-481

\section{INTRODUCTION}

Electronic cigarettes (e-cigarettes) are rapidly gaining popularity as a nicotine alternative to traditional cigarettes. Common reasons for using e-cigarettes include the perception they are healthier than traditional cigarettes and to aid in smoking cessation [1]. Despite increasing usage, there is a paucity of data on the physiologic impact of this nicotine supplement on surgical outcomes. We present a case of significant skin flap necrosis and breast reconstruction failure following bilateral mastectomy and immediate tissue expander reconstruction after a patient reported to be a non-smoker despite significant e-cigarette use. We further provide a review of the literature concerning the impact of e-cigarettes on surgical outcomes. 


\section{METHODS}

Pubmed and Ovid MEDLINE were queried for the terms "ecigarette", "electronic cigarette", "e-cig", "electronic nicotine delivery system”, “vaping”, “surgery”, "surgical”, "peri-operative”, "operate", "operative", and "wound healing". Eligible articles included animal studies, clinical trials and reviews of the literature (including opinion pieces) if they pertained to e-cigarette use in the perioperative period. Search was limited to publications in the English language through June of 2016. Data extraction included patient willingness to try e-cigarettes for smoking cessation in the perioperative period, effects on postoperative complications and surgeon opinion on e-cigarette use in the perioperative period.

\section{RESULTS}

The literature search returned 123 articles, which underwent title review. Of those, 29 underwent manual full text review, from which three articles were found to be relevant to e-cigarette's impact on surgical outcomes.

While an abundance of opinion pieces and summaries of e-cigarette use and potential hazards exist, only these three articles commented on possible complications associated with e-cigarette use in surgical patients. One was a published abstract by Rau et al. [2], which studied the effect of tobacco cigarette smoke, $1.2 \%$ e-cigarette vapor and $2.4 \%$ e-cigarette vapor on random pattern flaps compared to room air in rats. It was found that all three study groups were not significantly different from each other and all experienced a significantly higher percentage of flap necrosis than the rats exposed to room air. The second was a pi- lot study showing study subjects smoking electronic cigarettes exhibited decreases in cutaneous blood flow [3]. The third was a case report by Krishnan et al. [4] which reported a case of bilateral muscle-sparing transverse rectus abdominis (TRAM) flaps that experienced multiple episodes of vasospasm in a woman smoking e-cigarettes. Upon operative exploration the arterial and venous anastomoses were noted to be intact without kinking and the patient was started on oral Nifedipine daily for presumed vasospasm with subsequent uneventful postoperative course. Summaries of these three articles can be found in Table 1 .

\section{Case}

A 51-year-old female with a 25 pack year smoking history and newly diagnosed right breast cancer underwent right skin sparing mastectomy with sentinel lymph node biopsy, left prophylactic skin sparing mastectomy and immediate tissue expander reconstruction at our institution. The patient had right breast stage IA multifocal invasive ductal carcinoma and multifocal ductal carcinoma in situ (DCIS). Margins were negative with invasive carcinoma closest at $0.7 \mathrm{~cm}$ and DCIS closest at $0.5 \mathrm{~cm}$. Sentinel lymph node biopsy was negative for metastatic carcinoma. The patient denied history of coronary artery disease, myocardial infarction, congestive heart failure, diabetes mellitus, kidney or lung disease, venous thromboembolism, or any bleeding disorders. She likewise denied drug use or daily alcohol consumption. Having stopped smoking for several months prior to the surgery, the patient did not consider herself a smoker and reported herself as a "non-smoker". On physical examination, she had 40 DD cup breasts with grade 3 ptosis. The patient was deemed an American Society of Anesthesiologists Physical Status of 2 , indicating mild systemic disease. She was a good candi-

Table 1. Articles related to the effect of e-cigarettes on surgical outcomes

\begin{tabular}{|c|c|c|c|c|c|c|}
\hline No. & Authors & Title & Journal & $\begin{array}{c}\text { Publication } \\
\text { date }\end{array}$ & $\begin{array}{l}\text { Type of } \\
\text { study }\end{array}$ & Summary \\
\hline 1 & Rau et al. [2] & $\begin{array}{l}\text { Electronic cigarettes are as toxic } \\
\text { to skin flap survival as tobacco } \\
\text { cigarettes. }\end{array}$ & $\begin{array}{l}\text { Plastic and } \\
\text { Reconstructive } \\
\text { Surgery Global } \\
\text { Open }\end{array}$ & 2016 May & Abstract & $\begin{array}{l}\text { Compares the effect of vapor from e-cigarettes to that of } \\
\text { traditional cigarettes (and a control group) on skin flap } \\
\text { necrosis in a rat model. This study found that rates } \\
\text { exposed to e-cigarettes have the same rates of skin flap } \\
\text { necrosis as those exposed to traditional cigarettes, and } \\
\text { significantly higher rates of skin flap necrosis compared to } \\
\text { a control group. }\end{array}$ \\
\hline 2 & Page et al. [3] & $\begin{array}{l}\text { The acute effects of electronic } \\
\text { cigarette smoking on the } \\
\text { cutaneous circulation. }\end{array}$ & $\begin{array}{l}\text { Journal of Plastic, } \\
\text { Reconstructive } \\
\text { and Aesthetic } \\
\text { Surgery }\end{array}$ & $2016 \mathrm{Apr}$ & Pilot study & $\begin{array}{l}\text { Preliminary results demonstrated that e-cigarette use results } \\
\text { in reduced cutaneous blood flow when monitored using } \\
\text { thermal imaging technology. The authors hypothesize that } \\
\text { that e-cigarette use may impair wound healing and have } \\
\text { adverse effects on surgical outcomes. }\end{array}$ \\
\hline 3 & Krishnan et al. [4] & $\begin{array}{l}\text { Can e-cigarettes cause free flap } \\
\text { failure? A case of arterial } \\
\text { vasospasm induced by electronic } \\
\text { cigarettes following microsurgical } \\
\text { breast reconstruction. }\end{array}$ & $\begin{array}{l}\text { Plastic and } \\
\text { Reconstructive } \\
\text { Surgery Global } \\
\text { Open }\end{array}$ & 2016 Jan & Case study & $\begin{array}{l}\text { Reported a case of a 48-year old female patient undergoing } \\
\text { bilateral muscle-sparing TRAM flaps who experienced } \\
\text { multiple episodes of vasospasm during her postoperative } \\
\text { course. It was later revealed that the patient had been } \\
\text { smoking e-cigarettes until the day of surgery. }\end{array}$ \\
\hline
\end{tabular}


Fig. 1. Mastectomy skin flap necrosis in patient using e-cigarettes

A 51-year-old female with a 25 pack year smoking history underwent bilateral mastectomy and immediate tissue expander reconstruction for newly diagnosed right breast cancer at our institution. Her postoperative course was complicated by extensive bilateral mastectomy skin flap necrosis, as demonstrated here. This photograph was taken approximately 3 weeks after mastectomy and tissue expander insertion.

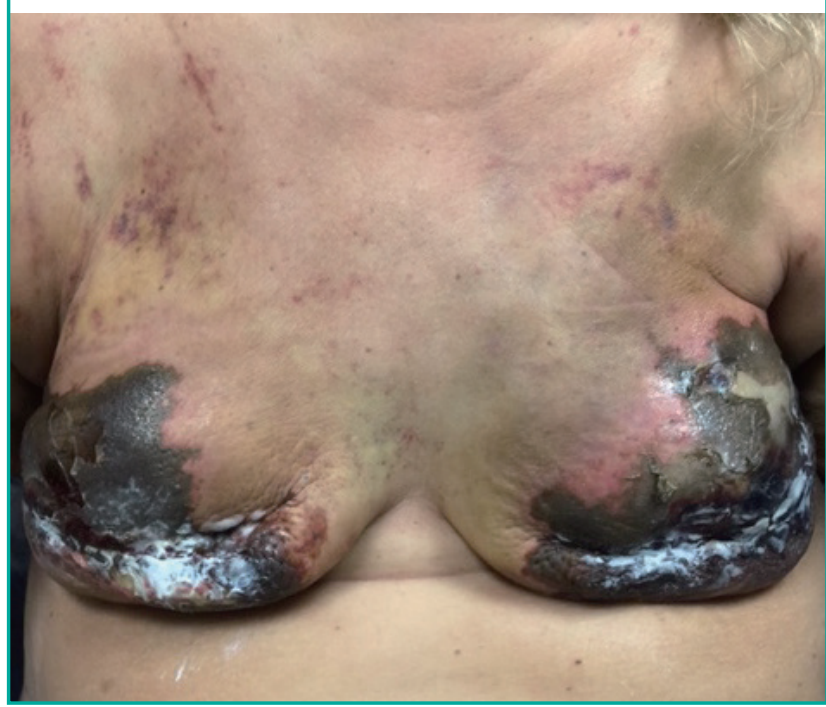

date for skin sparing mastectomy because her breasts were not pendulous. $700 \mathrm{~mL}$ fill tissue expanders were placed sub-pectorally with Flex HD support for the inferolateral breast pocket. Each expander was filled with $500 \mathrm{~mL}$ intraoperatively. At conclusion of the mastectomy, her flap appeared viable with good capillary refill. At completion of expander placement, her flaps continued to appear very viable. Her postoperative course was complicated by extensive bilateral mastectomy skin flap necrosis (Fig. 1). This was managed with tissue expander removal, debridement and primary closure two weeks after her initial surgery given the need to start chemotherapy. It was only after post-hoc questioning that the patient revealed that she was actively engaging in e-cigarette use. Indeed, she noted switching to e-cigarettes approximately 3 months prior to her surgery due to the belief they were safer than traditional cigarettes and maintained a usage similar to her previous 1.5 pack per day amount.

\section{DISCUSSION}

It is well-established smoking in the perioperative period negatively impacts surgical outcomes. Specific to plastic surgery procedures, nicotine mainly increases risk of skin flap necrosis and surgical site infection [5]. Smokers undergoing facelifts have a 13-fold increased risk of skin flap necrosis compared to nonsmokers [6]. Smokers undergoing TRAM breast reconstruction have higher rates of mastectomy and abdominal skin flap necrosis, with rates markedly increased after a 10 pack year smoking history [7]. Patients undergoing head and neck reconstruction have significantly higher wound complications with preoperative cotinine levels above $10 \mathrm{mg} / \mathrm{dL}$, giving a measurable target for when smoking interventions could be beneficial to outcomes [8]. Controversial findings exist with regard to cigarette smoking's effect on free flap outcomes; some suggest smoking decreases rates of microvascular anastomosis patency with resulting increases in flap loss while others find no effect $[7,9,10]$. A thorough summary of the negative effects of smoking on a whole range of plastic surgery procedures was described by Rinker [11] in 2012.

With increasing awareness of the adverse effects of traditional cigarette smoking, alternative nicotine options are gaining popularity. E-cigarettes are one such option. Marketed as "healthier" and "cleaner", they are often viewed as a better option to traditional cigarettes [12].

While traditional cigarettes deliver a host of toxic agents in addition to nicotine, the content of e-cigarettes is less well known (Table 2). Nicotine delivery may actually be similar to that of traditional cigarettes, though there is inconsistency between labeled and actual nicotine content of e-cartridges, as well as between nicotine levels in cartridges versus the aerosolized form [13]. Inconsistencies are also seen in plasma nicotine levels; while levels seem to be lower in those using nicotine replacement therapy compared to traditional cigarettes, similar rises are seen after smoking e-cigarettes and traditional cigarettes $[14,15]$. Ultimately, nicotine levels are largely dependent on patient smoking habits, which can vary widely.

E-cigarette vapor also demonstrated cytotoxicity to endothelial cells, whether or not nicotine was present. Additionally, despite Groniewicz findings of decreased nitrosamines in the $11 \mathrm{e}$ cigarette brands tested, there still remains significant variability among brands [16]. In fact, e-cigarettes can contain more nicotine than traditional cigarettes. E-cigarettes may have just as much of a detrimental effect on tissue oxygenation as traditional cigarettes given study subjects demonstrated decreases in subcutaneous blood flow with e-cigarette use [3].

Marketing of e-cigarettes relies heavily on the perception that they have a role in smoking cessation programs. Unfortunately, several studies have shown e-cigarette users have lower rates of smoking cessation compared to never users $[12,17]$. Other studies have shown e-cigarettes may aid in smoking cessation with quit rates similar to that of other nicotine replacement strategies and may have a more beneficial effect in reducing the number of cigarettes consumed per day [18]. However, without more data on complication rates of e-cigarettes in surgical pa- 
Table 2. Comparison between traditional cigarettes and e-cigarettes

\begin{tabular}{|c|c|c|}
\hline Components & Traditional cigarettes & Electronic cigarettes \\
\hline Major constituents & $\begin{array}{l}\text { Nicotine } \\
\text { Carbon monoxide } \\
\text { Nitrosamines } \\
\text { Aromatic hydrocarbons } \\
\text { Aldehydes } \\
>4,000 \text { Chemical compounds }\end{array}$ & $\begin{array}{l}\text { Nicotine } \\
\text { Propylene glycol } \\
\text { Glycerol } \\
\text { Flavoring }\end{array}$ \\
\hline Effects on inflammatory cells & $\begin{array}{l}\text { Increase in inflammatory cytokines, such as IL-1 and TNF-alpha } \\
\text { Increase number and reactivity of neutrophils in the blood stream } \\
\text { Decrease in neutrophil and monocyte chemotaxis } \\
\text { Decrease in neutrophil and macrophage migration into wounded } \\
\text { issue } \\
\text { Decrease in neutrophil and macrophage oxidative burst and } \\
\text { phagocytic activity, resulting in decreased ability to clear wounds } \\
\text { of bacteria } \\
\text { Increase in proteolytic enzymes (specifically MMP-8 and MMP-9) } \\
\text { leading to increased collagen degradation and weaker wound } \\
\text { strength } \\
\text { ROS inhibit anti-proteases }\end{array}$ & $\begin{array}{l}\text { No increase in WBC } \\
\text { Decreased density and viability of Kupffer cells } \\
\text { Increase complement protein activation and deposition onto liver } \\
\text { Kupffer cells } \\
\text { Enhanced C1q receptor expression on Kupffer cells } \\
\text { Increase Kupffer cell cytokine release } \\
\text { Enhanced hydrogen peroxide production due to increased xanthine } \\
\text { oxidase and peroxidase activity } \\
\text { Decreased epithelial cell, alveolar macrophage and neutrophil anti- } \\
\text { microbial activity against staph aureus } \\
\text { Upregulation of certain inflammatory markers and acute phase } \\
\text { reactants } \\
\text { Some vapor extracts promote ROS formation }\end{array}$ \\
\hline $\begin{array}{l}\text { Effects on cellular proliferation } \\
\text { and wound healing process }\end{array}$ & $\begin{array}{l}\text { Reduced fibroblast proliferation } \\
\text { Reduced pro-collagen (I and III) and collagen (I and III) synthesis } \\
\text { Reduced hydroxyproline accumulation } \\
\text { Likely reduced endothelial angiogenesis } \\
\text { Reduced epidermal regeneration with thinner epidermis and stratum } \\
\text { corneum and reduced epidermal barrier } \\
\text { Reduced levels of Vitamin C and E, with reduced ability to clear } \\
\text { ROS and increased defective collagen synthesis } \\
\text { ROS contribute to increased destruction of cell membranes, } \\
\text { endothelial dysfunction and cellular apoptosis }\end{array}$ & $\begin{array}{l}\text { Enhanced epithelial cell death with exposure to vapor extract } \\
\text { Decreased endothelial cell proliferation } \\
\text { Increased DNA strand breaks in epithelial and squamous cell lines } \\
\text { exposed to e-cigarette vapor, with or without nicotine }\end{array}$ \\
\hline Effects on clotting cascade & $\begin{array}{l}\text { Increase in platelet activation } \\
\text { Increase circulating fibronectin } \\
\text { Overall increased propensity to form blood clots }\end{array}$ & Largely unknown \\
\hline Effects on blood vessels & $\begin{array}{l}\text { Oxidative stress on endothelial cells } \\
\text { Induces vasoconstriction } \\
\text { Inhibits endothelial-dependent vasodilation } \\
\text { Stimulates catecholamine release and adrenergic stimulation } \\
\text { contributing to vasoconstriction }\end{array}$ & $\begin{array}{l}\text { Cytotoxic to endothelial cells, whether or not vapor contains nicotine } \\
\text { Morphologic alterations to endothelial cells, including disruptions to } \\
\text { endothelial cell barrier and cell-to-cell contacts }\end{array}$ \\
\hline Effects on tissue oxygenation & $\begin{array}{l}\text { Vasoconstriction induces hypoxia } \\
\text { Decreased subcutaneous blood flow } \\
\text { Decreased tissue oxygen tension } \\
\text { Increased lactate levels and anaerobic metabolism in tissue } \\
\text { Carbon monoxide shifts oxygen dissocation curve to the left and has } \\
200 \text { times higher affinity for hemoglobin, decreasing oxygen } \\
\text { delivery to peripheral tissues }\end{array}$ & Reduced cutaneous blood flow \\
\hline Cardiovascular effects & $\begin{array}{l}\text { Accelerated atherosclerotic disease } \\
\text { Increased risk of } \mathrm{CAD} \text { and } \mathrm{MI}\end{array}$ & $\begin{array}{l}\text { Smokers switching to e-cigarettes with elevated systolic blood } \\
\text { pressure at baseline demonstrate a decrease in systolic blood } \\
\text { pressure after } 1 \text { year of smoking cessation with e-cigarette use }\end{array}$ \\
\hline Pulmonary effects & $\begin{array}{l}\text { Increased risk of lung cancer } \\
\text { Increased risk of COPD and other lung disorders }\end{array}$ & $\begin{array}{l}\text { Increased dynamic airway resistance } \\
\text { Increased expired NO } \\
\text { Airway colonizer staph aureus demonstrates increased virulence, } \\
\text { biofilm formation and enhanced invasion of host epithelial cells } \\
\text { when exposed to vapor extract }\end{array}$ \\
\hline Associated surgical complications & $\begin{array}{l}\text { SSI } \\
\text { Delayed wound healing } \\
\text { Wound dehiscence } \\
\text { Incisional hernia } \\
\text { Skin flap necrosis } \\
\text { Tissue flap necrosis }\end{array}$ & $\begin{array}{l}\text { Increased distal skin flap necrosis in rats } \\
\text { Largely unknown in humans }\end{array}$ \\
\hline
\end{tabular}


tients, using them to assist with smoking cessation prior to surgery is of unknown benefit. Given that many smokers undergoing elective surgery have expressed interest in using e-cigarettes as a means to abstain from smoking in the perioperative period, more data about their safety must be evaluated [19]. Despite limited objective data, evidence suggests e-cigarettes may induce some of the same physiologic changes as traditional cigarettes, with or without nicotine present, and may have a significant deleterious effect on wound healing.

\section{Limitations}

Our review of the literature demonstrates the lack of data published about e-cigarettes in a surgical population and some suggestion of association with complications such as skin necrosis and vasospasm. As such, they should be considered equivalent to traditional cigarettes until more information about their safety and toxicity is available, particularly in plastic surgery patients undergoing elective operations. This review is limited by a focus on the surgical literature and did not delve into general reviews of e-cigarettes in the medical literature. It is also significantly limited by the paucity of available objective data on e-cigarettes in the surgical literature, as can be seen from the lack of randomized, controlled trials.

\section{CONFLICT OF INTEREST}

No potential conflict of interest relevant to this article was reported.

\section{PATIENT CONSENT}

The patient provided written informed consent for the publication and the use of their images.

\section{REFERENCES}

1. Etter JF, Bullen C. Electronic cigarette: users profile, utilization, satisfaction and perceived efficacy. Addiction 2011; 106:2017-28.

2. Rau A, Reinikovaite V, Ford J, et al. Electronic cigarettes are as toxic to skin flap survival as tobacco cigarettes. Presented at the American Association of Plastic Surgeons 95th Annual Meeting; 2016 May 21; New York, USA.

3. Page F, Hamnett N, Wearn C, et al. The acute effects of electronic cigarette smoking on the cutaneous circulation. J Plast Reconstr Aesthet Surg 2016;69:575-7.

4. Krishnan NM, Han KD, Nahabedian MY. Can e-cigarettes cause free flap failure? A case of arterial vasospasm induced by electronic cigarettes following microsurgical breast reconstruction. Plast Reconstr Surg Glob Open 2016;4:e596.

5. Knobloch K, Gohritz A, Reuss E, et al. Nicotine in plastic surgery: a review. Chirurg 2008;79:956-62.

6. Rees TD, Liverett DM, Guy CL. The effect of cigarette smoking on skin-flap survival in the face lift patient. Plast Reconstr Surg 1984;73:911-5.

7. Chang DW, Reece GP, Wang B, et al. Effect of smoking on complications in patients undergoing free TRAM flap breast reconstruction. Plast Reconstr Surg 2000;105:2374-80.

8. Marin VP, Pytynia KB, Langstein HN, et al. Serum cotinine concentration and wound complications in head and neck reconstruction. Plast Reconstr Surg 2008;121:451-7.

9. van Adrichem LN, Hoegen R, Hovius SE, et al. The effect of cigarette smoking on the survival of free vascularized and pedicled epigastric flaps in the rat. Plast Reconstr Surg 1996; 97:86-96.

10. Yaffe B, Cushin BJ, Strauch B. Effect of cigarette smoking on experimental microvascular anastomoses. Microsurgery 1984;5:70-2.

11. Rinker B. The evils of nicotine: an evidence-based guide to smoking and plastic surgery. Ann Plast Surg 2013;70:599-605.

12. Adkison SE, O'Connor RJ, Bansal-Travers M, et al. Electronic nicotine delivery systems: international tobacco control four-country survey. Am J Prev Med 2013;44:207-15.

13. Goniewicz ML, Hajek P, McRobbie H. Nicotine content of electronic cigarettes, its release in vapour and its consistency across batches: regulatory implications. Addiction 2014; 109:500-7.

14. Benowitz NL. Pharmacology of nicotine: addiction and therapeutics. Annu Rev Pharmacol Toxicol 1996;36:597-613.

15. Flouris AD, Chorti MS, Poulianiti KP, et al. Acute impact of active and passive electronic cigarette smoking on serum cotinine and lung function. Inhal Toxicol 2013;25:91-101.

16. Grana RA, Popova L, Ling PM. A longitudinal analysis of electronic cigarette use and smoking cessation. JAMA Intern Med 2014;174:812-3.

17. Popova L, Ling PM. Alternative tobacco product use and smoking cessation: a national study. Am J Public Health 2013;103:923-30.

18. Polosa R, Caponnetto P, Morjaria JB, et al. Effect of an electronic nicotine delivery device (e-Cigarette) on smoking reduction and cessation: a prospective 6-month pilot study. BMC Public Health 2011;11:786.

19. Kadimpati S, Nolan M, Warner DO. Attitudes, beliefs, and practices regarding electronic nicotine delivery systems in patients scheduled for elective surgery. Mayo Clin Proc 2015;90:71-6. 